\title{
Western Intellectual Insights for Muslim Policy Makers on Religion Based Economy
}

\author{
Mohammad Manzoor Malik
}

\begin{abstract}
The subject of relationship between religion and economy raises many issues. It touches the originality of religion and economy and their nature of relationship including their independence and dependence. Western scholarship on the subject has useful insights for the Muslim policy makers on religion based economy. This research undertakes Marx and Weber's thought on the subject and relates the issue with the current reality in industrialized countries such as Singapore. The findings show that Marx is a reductionist and Weber's thesis highlights the independent role of religion in fostering economy although he remains pessimistic regarding its religiosity. The more plausible view is that though religion is an independent variable, yet there is interdependence between religion and economy. The economical modalities influence religious life in many ways. This challenge calls Muslim policy makers for a continuous intellectual effort in making creative contributions in making religion based economy possible.
\end{abstract}

Index Terms-Economy, religion, Islam, Marx, Weber, Singapore.

\section{INTRODUCTION}

The subject of the relationship between religion and economy has become an interesting study area in the contemporary time. Islamic banking and financial institutions have now greater visibility in many majority Muslim countries and a few non-majority Muslim countries. The rationale of this interest is that economy based on Islamic values is necessary for Muslims because conducting economical activities in accordance to religious ethical guidelines is an essential part of being a faithful believer. Beside many values and virtues in Islamic business ethics usury, deception, uncertainty, and doubtful transactions, which are very much part of modern economy, are prohibited However, there is a long way to go for Islamic economical and financial systems to make a significant mark at international level. There is a risk of losing the religiosity of these systems or succumbing to the dominant secular systems. Therefore, theorizing on the subject of religion based economy is in need of paying attention to cosmopolitan wisdom related to the subject. In a like manner, to understand the nature of the relationship between economy and religion, this study undertakes Western scholarship as a historical experience and theorizing and connects it with present developments in the economically developed regions, thus concluding into insights and lessons for Muslim policy

Manuscript received May 29, 2014; revised July 30, 2014.

Mohammad Manzoor Malik is with the Department of Fundamental and Inter-Disciplinary Studies, Kulliyyah of Islamic Revealed Knowledge and Human Sciences, International Islamic University Malaysia (e-mail: philomalik@iium.edu.my). makers on religion based economy.

This study is essentially a critical examination of the views of Karl Heinrich Marx (5 May 1818 - 14 March 1883) and Karl Emil Maximilian Weber (21 April 1864 - 14 June 1920) on religion and economy. The first section explains Marx and Weber's thought on the subject, and the second section maintains Weber's view in a modest way and argues that Marx is a reductionist. The third section shows that while the religion has contributed to economy, in the same way economy does affect religious life in many ways. This signifies the relationship and dynamics between religion and economy, leaving space for Muslim theorists to engage into continuous intellectual effort in sustaining religious values in economical developments.

Marx and Weber share their intellectual interest in economy; especially in the advent, origins, and the future of capitalism. There are converging trends in their thinking, both of them are intellectually uncomfortable with capitalism; but, at the foundational level, which is connected to the origin of capitalism, their thoughts remain radically divergent. Marx constructs his theory of capitalism on dialectical materialism and considers religion as solely dependent on economy, a form of alienation. Unlike Marx, Weber theorizes that Protestantism largely contributed to the development of the spirit, advent, and spread of capitalism. A modest reading of Weber's thesis shows that religion is not the only factor, which contributed to the development of capitalism; but, indeed, it is the major factor. Both Marx and Weber were uncomfortable with capitalism and its future; but while Marx expected a revolution, Weber saw no way out of the "iron cage". Marx was therefore interested in theorizing the coming communist revolution, Weber was more interested in exploring the reasons which led to the development of capitalism.

\section{KARL MARX ON ECONOMY}

Karl Marx was a German economist, philosopher, historian, and sociologist. Marx along with Engels founded philosophy based on dialectical materialism. In Economic and Philosophical Manuscripts he used the concept of alienation. The Communist Manifesto had worldwide influence on politics. Preface to A Critique of Political Economy was followed by Capital in which he examined capitalism by materialistic understanding of Hegel's dialectic. He held that "the economic base of society, involving the forces and relations of production, determines its ideological and cultural superstructure, and that contradictions between base and superstructure would, as a matter of historical inevitability, lead to social revolution and socialism" [1]. 
To understand Marx's ideas on economy and religion, it is indispensable to see how Marx develops his ideas. Marx in fact reinterprets and reverses Hegel's idealism. Hegel's idealism states matter is spirit and the world of physical objects consist of ideas either in our own mind or of ideas in some other mind: "its central point is that there is only one ultimately real thing, the Absolute, which is spiritual in nature. Other things are partial aspects of this, or illusory appearances generated by it" [2]. Hegel believed in rationality of history and optimistic progress. He developed the notion of thesis, antithesis, and synthesis, and its repetition, which came to be known as dialectic, and this dialectic results in historical progress and thought [3]. Marx adopted the dialectic and contradiction in Hegelian philosophy and used them to explain the material and social changes. Marx converted Hegelian idealism into historical materialism by suggesting that the basis of historical development is the development of material modes of production; hence, he produced a materialist philosophy of history.

Marx's philosophical materialism estimates that it is matter, which is first, not the spirit. Marx believes that the historical changes are dependent on the techniques and modes of production. Human history progressed in four stages: primitive community, the slave company, the feudal mode, and the capitalist mode. Marx focuses on the last stage, which is capitalism, its development, its disadvantages, and its anticipated fall and finally the advent of communism.

Marx claims that changes take place because of dialectical materialism through the struggle of classes. And dialectical materialism is as follows:

In opposition to idealism, it holds that matter is the primary being and that mind is subordinate. Matter can exist without mind, but mind cannot exist without matter. Sense experience reveals the existence of an external and objective world. In contrast to mechanistic materialism, it holds that the material world is not static. Things are full of contradictions or opposites, which drive them into a continuous process of development. This development is progressive through recognizing and reconciling the inherent contradictions [1].

The social changes are therefore based on material life which makes humans different from the animals. Marx claims "[Men] begin to distinguish themselves from animals as soon as they begin to produce their means of subsistence. . By producing their means of subsistence men are indirectly producing their material life" [4]. In 1867, Karl Marx presented his thoughts on the emergence of capitalism in an essay entitled The Origins and Development of Capitalism. The work suggested that human social organization is a human creation based on modes of production. And changes in societies happen when modes of production change. In result, a new class and a new form of society emerges. Merchants were inferior during Feudalism that developed in Europe in the 8th century; however, merchants grew in number and became powerful as the result of urbanization.

Marx identified the 16th and 17th centuries as being periods of intense capital accumulation as a direct consequence of the discovery, colonization and exploitation of the Americas, and the development of maritime trade with the East Indies and China. Thus began a process in the development of commercial capitalism, in contrast to the feudal capitalism that preceded it. So also began the rise of a new class within medieval European society, that is, the capitalist class, or as Marx liked to call them, the bourgeoisie [5].

Marx reduces all of human life and history to economy; the economy generates division of labor, class struggle, and all the social institutions, which are supposed to maintain the status quo. According to Marx, social institutions are superstructure built upon the base of economy; they are very dependent upon material and economic realities and nothing else. All of the institutions, which are prominent in our daily lives such as religion, can be truly understood when examined in relation to economic forces. The following section presents Marx's particular views on religion.

\section{Marx on Religion}

Marx did not write any exclusive work on religion, even so his ideas have significant impact on the sociology of religion. Religion, according to him, is one of the superstructures which are based on economy; it is one of those social institutions that are dependent upon the material and economic realities in a given society. It has no independent existence; it is instead the result of productive forces. As Marx wrote, "The religious world is but the reflex of the real world" [4]. Marx gives the following account on religion.

Man makes religion, religion does not make man. Religion is indeed man's self-consciousness and self-awareness so long as he has not found himself or has already lost himself again. But, man is no abstract being squatting outside the world. Man is the world of man - state, society. This state and this society produce religion, which is an inverted consciousness of the world, because they are an inverted world. Religion is the general theory of this world, its encyclopedic compendium, its logic in popular form, its spiritual point d'honneur, it enthusiasm, its moral sanction, its solemn complement, and its universal basis of consolation and justification. It is the fantastic realization of the human essence since the human essence has not acquired any true reality. The struggle against religion is, therefore, indirectly the struggle against that world whose spiritual aroma is religion [6].

However, Marx has more to say on religion, its role, and how it fits to his theory of economics. His most famous statement about religion comes from Critique of Hegel's Philosophy of Right:

Religious suffering is at one and the same time the expression of real suffering and a protest against real suffering. Religion is the sigh of the oppressed creature, the heart of a heartless world and a soul of soulless conditions. It is the opium of the people.

The abolition of religion as the illusory happiness of the people is the demand for their real happiness. The call on them to give up the condition that requires illusions [4].

Therefore, religion has no role in contributing to economy, it is a substructure, and it is just a dependent variable, a symbol of alienation. Religion helps to maintain the status quo, which is based on economic facts, and it provides comfort to those who are alienated without any implication to economy. Its form and scope depends on the social life as 
determined by those in control and "the ideas of the ruling class are in every epoch the ruling ideas" [7].

The concept of alienation is very important in Marx's thought. Marx discusses types of alienations which are related to capitalism. The meaning of alienation is that it "is the negative process by which a subject makes himself other than himself by virtue of a constraint which is capable of being removed on the initiative of the subject himself" [8]. Marx considers religion as self-alienation. It helps people to live an illusory life; it makes them bear the injustice and difficult life. Religion is opium in the sense that it makes downtrodden people's difficult life more bearable. Religion becomes the heart for those who are distressed by providing an illusory comfort to them which may mean either afterlife or next life. "Religion offers compensation for the hardships of this life in some future life, but it makes such compensation conditional upon acceptance of the injustices of this life" [9]. Marx suggests that this form of alienation deserves to be discarded.

The abolition of religion as the illusory happiness of the people is the demand for their real happiness. To call on them to give up their illusions about their condition is to call on them to give up a condition that requires illusions. The criticism of religion is, therefore, in embryo, the criticism of that vale of tears of which religion is the halo [4].

\section{MAX WEBER ON RELIGION AND ECONOMY}

Max Weber (1864 - 1920) was a German sociologist and economist. Weber's writings and theories helped establishment of the foundations of modern sociology. Weber's major works deal with rationalization in sociology of religion, government, organizational theory, and behavior. His interest in the relations between religion and social and economic conditions led to his influential theory that the development of European capitalism can be explained in terms of the ascetic secular consequences of Protestant theology. Weber's most influential works are The Protestant Ethic and the Spirit of Capitalism (1904-5) and Economy and Society [1].

The main theme of The Protestant Ethic and the Spirit of Capitalism is the influence and role of religion in social change; religion is an independent variable which can bring change. The work could be treated as a critique of Marx's view of religion. It mainly argues that the spirit which defines capitalist institutions has its roots in Protestantism, beginning with Lutheranism of Martin Luther, which emphasized salvation rests on faith alone, and John Calvin's Calvinism, which held that salvation is based on predestination.

\section{A. Weber's Thesis}

Max Weber develops a thesis in The Protestant Ethic and the Spirit of Capitalism: there is a causal relationship between the ethics of ascetic Protestantism and the emergence of the spirit of modern capitalism. Weber writes:

The inner-worldly asceticism of Protestantism first produced a capitalistic state, although unintentionally, for it opened the way to a career in business, especially for the most devout and ethically rigorous people. Above all, Protestantism interpreted success in business as the fruit of a rational mode of life [10].

Weber argues that Calvinists played a role in creating the capitalistic spirit, and Protestantism had a major role in the advent of capitalism. He supports his thesis by two lines of thought: empirical and theoretical. The empirical evidence is that there is a correlation between being Protestant and being involved in business; for that reason, Protestants have contributed to the advent of modern economical conditions. Theoretically, teachings of Protestantism that are in consistency with the spirit of capitalism such as profit maximization as an end in itself. He supports his claim by the Protestant teachings such as worldly "calling" and Calvinists understanding of predestination [11]. The other Protestant sects such as Pietist, Methodists, and the Baptist had the similar attitudes.

Weber concludes that the Protestant attitude to wealth and economy broke down the traditional economic system and paved the way for modern capitalism. Once capitalism emerged its ethic took on a life of its own without any further need of any Protestant values. Even so, Weber does not claim Protestantism as the only cause of capitalism; rather it was one of the main contributing factors.

Weber develops the above thesis by showing that capitalism in its unique scientific way emerged in the West, and this development was contributed by Protestants. He does it by making empirical and theoretical arguments. The Protestant Ethic and the Spirit of Capitalism begins with the question of rationalization; development of science; the development of rational, systematic, and specialized methodology; and the development of bureaucracy and the trained officials. Weber claims that these are the unique features of the Western society. In the same manner, capitalism emerged in the West in its unique way of rationalization which reflects through the spirit of capitalism and its features such as bookkeeping. Therefore, there is a link between the spirit of modern capitalism and the rational ethics of ascetic Protestantism [11].

\section{B. Capitalism and Protestants: Empirical and Theoretical Arguments}

Weber gives the major credit of the development of capitalism and its spirit to Protestantism. He does so, as mentioned earlier, by providing two kinds of arguments: empirical and theoretical. The empirical argument is that Protestants were more involved in capitalistic activities than Catholics. Based on his observations in Germany and elsewhere, Weber depicts a correlation between ascetic Protestantism and the spirit of capitalism.

By surveying different countries with mixed population coming from different religions, it seems that Protestants are dominantly business leaders, owners and skilled laborers. During protestant reformation Protestants emerged richer than Catholics. It is because Protestant parents tend to give their children different kinds of education and Catholics have more of a tendency than Protestants to stay in handicrafts rather than to go into industry [11]. Therefore, Protestants have shown a much stronger tendency to develop economic rationalism than Catholics have. To this end, Weber makes the following statement:

Business leaders and the owners of capital, as well as the 
skilled higher strata of the labor force and especially the higher technical or commercially trained staff of modern enterprises tend to be predominantly Protestant [11].

The theoretical argument, which Weber offers is that it was Protestantism which led to the development of capitalism and its spirit: it was Protestantism which was in consistency with what is considered as the spirit of capitalism. In explaining the above argument, Weber first explains the spirit of capitalism and notices similarities between ascetic Protestantism and the spirit of capitalism.

\section{Spirit of Capitalism and Protestantism}

Weber explains the spirit of capitalism as a body of salient features. The spirit of capitalism is accumulation of wealth for its own sake. That saving money or reinvesting it, instead of spending it, is an intrinsic good. Therefore, accumulation of wealth and its acquisition is not only a means for the satisfaction of material needs but also an end in itself. Weber's purpose of explaining the spirit of capitalisms is to show that the same characteristics of this spirit were propagated and taught by Protestantism.

In explaining the spirit of capitalism, Weber theorizes that Franklin's attitudes to economy illustrate capitalism's ethos. Franklin held that time is money, credit is money, and money can beget money. People should pay all of their debts on time, because it encourages the confidence of others, encouraging people to present themselves as industrious and trustworthy at all times. Weber says that this "gospel of avarice" sees increasing capital as an end in itself. This is the spirit of modern capitalism.

In fact, the summum bonum of this ethic, the earning of more and more money, combined with the strict avoidance of all spontaneous enjoyment of life, is above all completely devoid of any eudaemonistic, not to say hedonistic, admixture. It is thought of so purely as an end in itself, that from the point of view of the happiness of, or utility to, the single individual, it appears entirely transcendental and absolutely irrational [12].

Weber commits his last four chapters of The Protestant Ethic and the Spirit of Capitalism to demonstrate the connection between the Protestant ethic and the spirit of capitalism. He goes on findings the evidences that could support his conclusions by looking at the various sects of Protestantism with a clear objective to find out how the teachings of these sects have actually contributed to the spirit of Capitalism by exploring their ethical teachings and thus providing the well-constituted evidence to justify the contribution of these Protestant sects to the economical development.

Historically, the four major forms of ascetic Protestantism are Calvinism, Pietism, Methodism, and the Baptist sects. Weber begins from Martin Luther's conception of "Calling". Lutheran conception of calling is that people are required to fulfill their worldly obligations as they are religiously significant. Different from Catholics and antiquity, this moral justification of the worldly activity was the contribution of Luther and of Reformation.

\section{Ascetic Protestants and the Spirit of Capitalism}

Weber finds support for his convictions in Calvinism, especially its doctrine of predestination: it is predestined who is saved and who is damned. It was important for them that an individual should try to realize that he is saved and therefore he/she should strive to realize so in this world. And an individual should consider himself one of the saved and should try to avoid temptations. Therefore, Calvinists encouraged worldly activities; they believed that humans are tools of God to fulfill his will. In conducting the worldly affairs, Calvinists expected systematic self-control. "The God of Calvinism demanded of his believers not single good works, but a life of good works combined into a unified system" [12]. This was a rational and systematic approach to life. Since people had to prove their faith through worldly activity, Calvinism demanded a kind of worldly asceticism. This Concept of predestination led to the development of rationalized ethics and methods which were used by Puritans. In brief, Calvinists did not live a monastic life but preferred to live worldly life; they were at the height of rationalism because their teachings disdained magic and stressed on systematic lifestyle [12].

Weber, after presenting the teachings of Calvinism, includes other Protestant sects which were consistent with the Calvinistic teachings. First, he mentions Pietism; Pietists believed that the methodical development of one's state of grace in terms of the law was a sign of grace. Secondly, they believed that God gives signs to those in states of perfection if they wait patiently and "deliberate methodically" [12]. Methodism strongest characteristic was its methodical and systematic nature of conduct. Good works were only the means of knowing one's state of grace. "Righteous conduct alone did not suffice", the feeling of grace was necessary for salvation [12]. "The Baptist denominations ... carried out the most radical devaluation of all sacraments as means to salvation, and thus accomplished the religious rationalization of the world in its most extreme form" [12]. They practiced worldly asceticism, rejected politics, and turned to economic occupations; they embraced the ethic of "honesty is the best policy" [12].

After presenting the above views of different Protestant sects, Weber reaches his conclusion: there is a direct relationship between ascetic Protestants and the spirit of capitalism. He mentions many points to demonstrate how this asceticism and the development of the spirit of capitalism are connected. The capitalistic sprit is to make money not as a means but as an end in itself. Asceticism opposed the hedonistic enjoyment of life; this helped in developing the professional altitude to work. Overall, ascetic Protestantism gave ethical dimensions to the Capitalistic way of life. Furthermore, it provided a religious zeal for the pursuit of wealth because result of one's labor was a sign of God's blessing.

Weber states that the teachings and influences of ascetic Puritanism by many sects of Protestantism created the modern economic order as far as the beginning and developing stage of capitalism is concerned. Latter on "The religious roots died out slowly, giving way to utilitarian worldliness" [12]; and "Since asceticism undertook to remodel the world and to work out its ideals in the world, material goods having gained an increasing and finally an inexorable power over the lives of men as at no previous period in history. Today the spirit of religious 
asceticism-whether finally, who knows?-has escaped from the cage. But victorious capitalism, since it rests on mechanical foundations, needs its support no longer" [12].

\section{E. Plausibility of Weber's Thesis}

Weber's thesis is particularly plausible in two areas. The first area is related to the theoretical foundations of his thesis. The theoretical foundations of his thesis rest on the teachings of Calvinism and other Protestant sects. The second area is the empirical foundations of his thesis. This empirical base is explicated in Weber's work and greatly supported by a huge number of researches conducted in support of Weber's thesis.

\section{F. Weber's Theoretical Argument}

Weber's theoretical point is that Calvinism was a major factor in the growth of modern rational capitalism. Calvinism and its teachings helped a change from the traditional form of thinking to the rational form of thinking. As far as Weber's presentation of theoretical lines and teachings of Protestantism are concerned, his presentations of these teachings seem undisputable. He has accurately represented the teachings of Protestants. For example, to verify Weber's claims about the teaching of Calvinism, Synods of Dort which is a religious document that is the basis of Calvinistic belief, is helpful [13]. Furthermore, In Protestantism and Capitalism: The Mechanisms of Influence, Jere Cohen revisits, reexamines, and tests the classic Weberian thesis that the beliefs and presuppositions of the English Puritans had influence on believer's economic activity [14].

To go into comparative details between Weber's presentation of Protestant faith and the sources of Protestantism is an area which is quite broad. However, the dispute is about whether the Protestant teachings were inspired by the material facts or they had their own origins. Some of the scholars claim that it was not the Protestantism which developed the spirit of capitalism. For example, Kurt Samuelsson claims "whether we start from the doctrines of Puritanism and 'capitalism' or from the actual concept of a correlation between religion and economic action, we can find no support for Weber's theories" [15]. On the other hand some works, by accepting Weber's thesis, blame religion for the disadvantages of capitalism. For example, H. M. Robertson claims "the Reformers read their Old Testament and, trying to imitate the Jews, became those detestable Puritans to whom we owe, not merely Grundyism and Podsnappery, but also (as Weber and Tawney have shown) all that was and still is vilest, cruelest, most anti-human in the modern capitalist system" [16].

The first claim discredits the role of Protestantism in the development of Capitalism. However, it seems that the development of capitalism was not just an idea, it was a practice, which was conducted by people, and majority of these people were Protestants. Even if the roots of capitalism were way beyond the Protestantism, it is still important to see that this beginning would have not developed into the well sophisticated system and professionalism if it had not found its presence among certain people who were Protestants. It was the adjustment and favorable response from the Protestantism which allowed the development of the spirit of capitalism by providing both religious ethics and competent people to carry the capitalism to is development. The same idea is shared by some scholars such as Daniel Bell, while arguing in favor of the element of Protestant ethics in the development of capitalism, makes the following statement:

What was also required was a religious ethic that provided justifications for conduct and sanctions for lapses. In the Protestant world view, all work (from the highest to the lowest) was a "calling" and thus sanctified, as against the view that work was a punishment for man's sin of disobedience. The idea of a calling, then--which Weber argued did not exist in previous religious or ethical codes--is a moral obligation that projects religious behavior onto the everyday world [17].

Therefore, the above-mentioned objections do not affect Weber's thesis. First, Weber does not make Protestantism the origin of capitalism, his thesis suggests that Protestantism has contributed to the spirit and development of capitalism. He does not make Protestantism the only reason and factor which led to the emergence of capitalism. The second objection, which blames Protestantism for the disadvantages of capitalism and fear of associating these ill effects to religion; this issue is also a weak position, because Weber states that Protestant ethics was favorable for the development of capitalism and once the capitalism came into existence it lost its connections with the Protestant ethics and therefore formed its own ethics and values. Magnús Árni Magnússon's research, on Max Weber's hypothesis of a faster economic growth of nations with predominantly Protestant populations using data from the twentieth century, concludes that although that might have been true during the early years of the modern period, the "Protestant edge" has given way to a universal "spirit of capitalism" belonging to those who wish to embrace it [18]. Therefore, religion cannot be made responsible for the ill effects and unkind consequences of capitalism. The researcher believes that Winthrop S. Hudson has captured the essence of this debate in the following statement:

Weber's initial statement of his thesis was frequently misread, misunderstood, and misinterpreted. Part of the difficulty was a failure to pay sufficient attention to Weber's definition of terms -- particularly what he meant by modern capitalism and the spirit of capitalism. Further difficulty was created by those who over-stated the points which Weber was seeking to establish. Even Tawney understood Weber to be asserting that Calvinism, by creating the indispensable psychological climate, was to a very large degree the "parent" of modern capitalism (Religion and the Rise of Capitalism).It is now contended, however, that those who interpreted Weber as saying that modern capitalism was the "offspring" of Calvinism misunderstood him. Weber, it is insisted, never made such a claim and was far too learned and sophisticated to have done so. His intention was much more modest. He was attempting to analyze but one of the many components of the total matrix out of which the capitalist spirit emerged. He did no more than suggest that Calvinism engendered a spirit that was congruent with the spirit of capitalism and thus facilitated the development of capitalist society (The Protestant Ethic and the Spirit of Capitalism: the History of a Controversy). This brings Weber, of course, largely into agreement with Tawney who said that " 'the capitalist spirit' is as old as history" and that what certain aspects of later 
Calvinism did was to provide "a tonic which braced its energies and fortified its already vigorous temper" (Religion and the Rise of Capitalism) [19].

\section{G. Weber's Empirical Argument}

This empirical base is explicated in Weber's work and greatly supported by a huge number of researches following the publication of Weber's thesis. There are many researches, which reinforce the empirical facts, which Weber has put forward in his work. In The Puritan Gift: Triumph, Collapse and Revival of an American Dream, the author traces the origins of contemporary management back to the strict disciplines of the Puritan Migrants of the 1630s and their flight to America. Furthermore, how the current management style has deviated from these Puritan principles [20]. Sascha O. Becker and Ludger Wößmann in Was Weber Wrong? A Human Capital Theory of Protestant Economic History have empirically founded the following conclusion:

Max Weber attributed the higher economic prosperity of Protestant regions to a Protestant work ethic. We provide an alternative theory, where Protestant economies prospered because instruction in reading the Bible generated the human capital crucial to economic prosperity. County-level data from late 19thcentury Prussia reveal that Protestantism was indeed associated not only with higher economic prosperity, but also with better education. We find that Protestants' higher literacy can account for the whole gap in economic prosperity. Results hold when we exploit the initial concentric dispersion of the Reformation to use distance to Wittenberg as an instrument for Protestantism [21].

The significant point in Weber's thesis is that Protestantism was a major factor in the growth of modern rational capitalism. Weber does not claim that it was the only factor. It is also obvious that Weber does not defend religion in general sense against Marx's criticism. Weber also shows that the western Catholicism did not make any significant contribution. This view of Weber is therefore not a general appreciation of religions in making contribution in an economical activity; it is rather appreciation of a special and unique interpretation of religion which grew in Protestantism.

Therefore, at most, it could be concluded that Protestantism was a major contributor to the economic development and the rise of capitalism. However, criticizing Marx's historical materialism and his view of religion as an alienation can be made on many other grounds, which may not fall mainly within the material and economical realms, but in other areas, which demonstrate that religion is an independent variable. As a set of ideas and practices, it can cause changes in many social areas including economy. It is not only economy, which affects the social structures, but also religion does cause changes in the society and in the practices related to economical activity.

\section{REFLECTIONS ON MARX AND WEBER}

The views of Marx and Weber on economy and religion demonstrate their ideas on capitalism and situate religion and its role in relation to economy. In Marx's view, religion has no role in the materialist capitalism; religion is a substructure, a self-alienation, helping deprived to sooth their pain. Weber's analysis of capitalism gives a major role to Protestantism in contributing to the development of capitalism.

From the above comparison, it is clear that Marx is a reductionist; he reduces everything to materialism. Matter is the independent variable whereas other social structures including religion are dependent variables. They are sub-structures and change according to the change in material variables. However, Marx's reductionist thesis is not defendable; yet influences of changing economical modules do have effects to religious practices in many ways especially in social organization. On the other hand, Weber's thesis is a defensible which states the influence of religion on economy. Marx's view is very radical and an extremist position. Against historical evidence, he altogether ignores the role of religion in social change. Weber's thesis is actually a detailed indirect criticism of Marx's thesis because Weber's thesis is on religion and its role in developing capitalism.

In arguing against Karl Marx's reductionist view there are two main areas of study. The first area is related to the investigation of Weber's thesis, to understand the correctness of it by researching the sources: researches, facts, and data. The credibility of Weber's thesis will in fact prove the incredibility of Marx's view. The second area is to investigate Marx's thesis and to find whether human life and social change are the product of economy alone when, in fact, especially religion has changed human life and has led to great social and sometimes holistic changes throughout history. Associated with this argument is that religion is a divine intervention in the society. It especially comes true about Western religions, which are not the result of human search, but a call from outside, based on revelation. Marx's view that religion is a tool, which is used by ruling class, is not also convincing. Though, religion can be misused in that sense, but the impact of religion on ruling class has been historically very transforming; the examples of Constantine in the Christian history and Asoka in the Buddhist history are worth mentioning. In a very striking way, removing all sorts of doubts on the issue, Islamic civilization, which was a leading civilization during the European dark ages, provides a special case as its inception and development could not be imagined without Islam. Muslim civilization was a practical development of Islam and its worldview. Buddhism came with Gautama Buddha, who was not the helpless and powerless to seek solitude in metaphysical truth, he was rather a prince born in a powerful family. In the similar way the prophet Muhammad (PBUH) belonged to one of the main, mightiest tribes of Arabia called Qurash.

The key problem, which is central in Marx's account of religion, is his reductionism. According to him, religion is a dependent variable. It has no influence of its own; rather it is influenced by economical systems. However, the historical evidences and examples show that religion has changed humanity and shaped its course. To illustrate this, it is within the context to go through the study of religions; and to see whether they were personifications of aberration, sigh of the poor, a poor man's paradise, and opium of powerful to distribute among those under their control; or is religion something else. 
Going back to Judaism, Moses by being given religion from God liberates his people from slavery of pharaoh. Here, religion does not seem suspiration of poor, but a force which coordinates the whole community to stand for their rights. The story of Exodus shows how a religion played a vital role in changing the life of the children of Israel. As the Old Testament states how religion helped in coordinating people and eventually brought revolution against the mighty pharaoh.

While reading the history Buddhism, its founder, Mahatma Buddha, was not a poor man. He came from a royal family and he was a prince. The religion was born in a rich man's house. It goes against Marx's view that religion is for poor and it will vanish once a better economical conditions emerge. The change which religion can bring in people and most of all in the ruling class could be well appreciated by citing the example of King Asoka in the history of Buddhism. Being a mighty king, he waged many wars, and it was the teachings of Buddhism that stopped him from further bloodshed. This example also shows the power of religion in changing not only ordinary people, but also kings.

While going through the history of Islam and Muslims, ample support is present which affirms that religion can bring a revolutionary change in society and people. Before the advent of Islam, Arabs were a small community, mostly nomads; they had no political influence and contribution to human civilization. It is just after Islam; they flourished and became able to set up magnificent civilization in Bagdad and Spain.

The above examples illustrate the fact that religion is an independent variable which is able to cause changes. The historical study of religions shows that they emerged in various societies to bring change in those societies. They were not submissive to their social circumstances and systems. That is why most of these religions in their beginning met opposition, criticism, hostility, and prosecution. On Marx's understanding of religion, the case should not be the way the history shows us. For example, Mahatma Buddha's criticism of his contemporary class based society and of materialism which was prevalent in his time; Jesus' criticism of his own society which was full of arrogance and pride; and the Prophet Mohammad's (PBUH) criticism of his society for worshiping many gods and practicing many social evils.

Religion has created developments in many areas of life and these developments have taken their own path as Weber mentions about the development of capitalism. The teachings of Protestantism mainly led to the development of capitalism and capitalism latter took its own path with its own ethics. In the similar way, Islam gave birth to a special state craft called as Khilafah which in long run turned into monarchical systems with its own principles while at the same time keeping some regard and respect for the actual nature of governing system that emerged in the first generation of Muslims.

\section{ECONOMY AND RELIGION}

The relationship between religion and economy as discussed in the above sections of this study shows that there is an interrelationship between religion and economy. It also appears that Weber's view supports that religion had a vital role to play in the advent of capitalism, and Marx's view suggests that economy has direct impact on religion; his view leads to end of religion when his Utopian economical state is realized. However, as argued above religion is not based on economy, but it has its own existence and effects to social practices.

However, there are implications and effects from economy to religious practice and institutions. This does not mean that the religion is a product of economy. In fact, there is a two-way relationship between economy and religion [22]. As economy influence our religious life, in the same way religion also influences economic practices. For example, the multinational companies operate in different countries which have different religions and cultures. These companies try to conduct their economic practices and shape their business operations in consistency and sensibility with cultural values and religions.

The impact of economy on religious institutions and practices can be seen throughout the human history. Leaving out the ancient and medieval times, the modern time, beside many other developments, brought the industrial revolution and capitalism. The economical development brought changes in social scene and affected cultural and religious values. The economy has affected all countries of the world at different levels with varied degrees.

In many Western countries church attendance as fallen seriously; it is, beside other reasons, because of the economical activities and workplace schedules. The Eastern countries where economical development is considerable, people have transformed their religious life in many ways. Industrialization and corporations have conditioned our way of living and economical changes have put humanity in a different and changing existential mode. How economical development has affected religious practices and challenged the religious lifestyles in almost every part of the world could be illustrated by a report on Singapore that speaks of some effects of economy to religious life. The report states:

Modernization and improved education levels brought changes in religious practice. The inflexible work schedules of industrialism, which tended to restrict communal ritual to evenings and Sundays, and the lack of opportunity or inclination to devote years to mastering ceremonial and esoteric knowledge, both contributed to a general tendency toward ritual simplification and abbreviation... Ethnic affiliation was demonstrated by public participation in such annual rituals as processions, which did not require elaborate training or study....Immigrants tended to drop or modify religious and ritual practices characteristic of and peculiar to the villages they had come from. ...Many Chinese became more self-consciously Buddhist or joined syncretic cults that promoted ethics and were far removed from the exorcism and sacrificial rituals of the villages of Fujian and Guangdong. ...Islamic reformers acted to replace the customary practices (adat) of the various Malay-speaking societies of Java, Sumatra, and Malaya with the precepts of classical Islamic law--sharia.... In the late 1980s, other Chinese white collar and skilled workers were joining the 
Japan-based Soka Gakkai (Value Creation Society, an organization based on Nichiren Buddhism), which provided a simple, direct style of worship featuring chanting of a few texts and formulas and a wide range of social activities. The more successful religious groups, Christian and Buddhist, offered directly accessible religious practice with no elaborate ritual or difficult doctrine and a supportive social group [23].

\section{CONCLUSION}

The subject of this study was basically to look into the nature of the relationship between religion and economy. Marx's historical materialism suggests that religion is just a substructure based on materialism or precisely on economy. Whereas, Weber demonstrates that Protestantism mainly contributed to the spirit of capitalism and its development. The study demonstrated Marx as a reductionist by showing that history of religions is contrary to Marx's position. The modest understanding of the issue shows that there is a two-way exchange between religion and economy. They both affect each other in many ways. Economy does influence religious life and institutions. This study puts forward many insights for Muslim policy makers on religion based economy. There are concerns the way Marx looks at the issue leaving economy overtaking every structure of the society and affecting ideas and outlooks. And on the other hand there are insights in Weber's thinking that puts high value on the role of religion in contributing to economy, yet he remains pessimistic believing that once economy progresses it takes its own life and breaks with religion. Both thinkers are pessimistic about the future of capitalism. These same insights could be made relevant to many other social institutions such as education, scientific progress, technology, etc. In short, these concerns and issues demand a continuous intellectual effort from Muslim theorists on religion based economy in making sustainability of religious virtues possible in overall developments in economy.

\section{REFERENCES}

[1] N. Bunnin and J. Yu, The Blackwell Dictionary of Western Philosophy, Blackwell Publishing, 2004, pp. 180-733

[2] A. R. Lacey, A Dictionary of Philosophy, 3rd ed. London: Routledge, 1996, pp. 143

[3] T. Bottomore, L. Harris, V. G. Kiernan, and R. Miliband, A Dictionary of Marxist Thought, ed. 2nd, Blackwell Publishing, 1991, p. 227.

[4] K. Marx, Marx on Religion, ed. J. Raines, Temple University Press, 2002, pp. 2-171.

[5] G. Dean. (September 1998). Karl Marx's the Origins and Development of Capitalism: A Review. [Online]. Available: http://okusi.net/garydean/works/Origins.html

[6] K. H. Marx, Early Writings, trans. R. Livingstone, G. Benton, and L. Colletti, Penguin Classics, 1992 , p. 244.
[7] K. Marx, Karl Marx: A Reader, ed. J. Elster, Cambridge University Press, 1986, pp. 302.

[8] H. Shagor. (2006). Marx and Religion: A Brief Study. [Online]. Available: http://www.mukto-mona.com/Articles/himel_shagor/

[9] M. Hamilton, The Sociology of Religion: Theoretical and Comparative Perspectives, Routledge, 1995, p. 83.

[10] M. Weber, The Sociology of Religion, trans. E. Fischoff, Boston: Beacon Press, 1993, p. 220.

[11] M. Weber, The Protestant Ethic and The "Spirit" Of Capitalism and Other Writings, trans. P. R. Baehr and G. C. Wells, Penguin Classics, 2002, pp. 1-321.

[12] M. Weber, The Protestant Ethic and the Spirit of Capitalism Weber, trans. Talcott Parsons, London: Charles Scribner's Sons., 1950, pp. 53-181.

[13] E. Crowell, "Weber's "protestant ethic" and his critics," The University of Texas, Arlington, 2006

[14] J. Cohen, Protestantism and Capitalism: The Mechanisms of Influence, Aldine Transaction, 2002.

[15] K. Samuelsson, Religion and Economic Action: A Critique of Max Weber, trans. E. G. French, New York: Harper Torchbook, 1964, pp 154.

[16] H. M. Robertson, Aspects of the Rise of Economic Individualism: A Criticism of Max Weber and His School, Cambridge, England: Cambridge University Press, 1933, pp. 208.

[17] D. Bell, "The protestant ethic," World Policy Journal, vol. 13, no. 3, pp. $35,1996$.

[18] M. Á. Magnússon, "The economic consequences of religion; max weber's 'spirit of capitalism'revisited," Bifrost School of Business 2002.

[19] W. S. Hudson, "The weber thesis reexamined," Church History: Studies in Christianity and Culture, vol. 57, no. Supplement, pp. 56, 1988.

[20] D. Howard. The Puritan Gift: Triumph, Collapse and Revival of an American Dream (Hardcover) [Review]. [Online]. Available: reviewhttp://www.amazon.co.uk/review/product/1850434190/ref=dp_ db_cm_cr_acr_txt?_encoding=UTF8\&showViewpoints $=1$

[21] S. O. Becker and Wößmann, "Was weber wrong?" A Human Capital Theory of Protestant Economic History, Department of Economics, University of Munich, University of Munich, Ifo Institute, CESifo, and IZA2007.

[22] R. J. Barro and R. M. McCleary, "Religion and economic growth," Massachusetts Avenue Cambridge, MA 02138: National Bureau of Economic Research, 2003.

[23] Singapore Religious Change. The Library of Congress Country Studies and the CIA World Factbook. [Online]. Available: http://www.photius.com/countries/singapore/society/singapore_societ y_religious_change.html

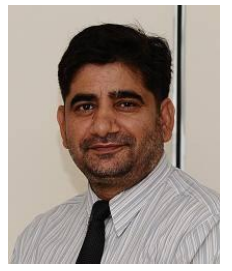

Mohammad Manzoor Malik is an assistant professor in the Department of Fundamental and Inter-Disciplinary Studies, Kulliyah of Islamic Revealed Knowledge and Human Sciences, International Islamic University Malaysia (IIUM). He received Alimiyat (BA) and Fazilat (MA) in Shariah with specialization in Islamic law and jurisprudence from Darul Uloom Nadwat-Ul-Ulama, Lucknow, India; in the meanwhile, he also earned BA and LL.B from Lucknow University. He furthered his studies in philosophy and obtained MA and PhD from Assumption University, Bangkok. His research interests are in moral philosophy, applied ethics, and bioethics. His competencies are in history of philosophy, Islamic studies, jurisprudence, hermeneutics, philosophy of mind, and philosophy of religion. 